\title{
Between Belonging and Longing: Why do Young Rural-urban Migrants Leave Their Places of Birth, What Do They Leave Behind, and Do They Consider Moving Back?
}

\author{
Gunnar Lind Haase Svendsen ${ }^{1 *}$ \\ ${ }^{1}$ Department of Sociology, Environmental and Business Economics, University of Southern Denmark, Niels Bohrs Vej 9 , \\ 6700 Esbjerg, DENMARK
}

\section{*Corresponding Author: glhs@sam.sdu.dk}

Citation: Svendsen, G. L. H. (2018). Between Belonging and Longing: Why do Young Rural-urban Migrants Leave Their Places of Birth, What Do They Leave Behind, and Do They Consider Moving Back?, Journal of Cultural Analysis and Social Change, 3(1), 02. https://doi.org/10.20897/jcasc/2671

Published: July 20, 2018

\begin{abstract}
This study is based on telephone interviews in 2012 with 25 arbitrarily chosen adolescents between 20-27 years who had recently migrated from the rural Danish municipality of Lemvig, supplemented with results from a 2011 survey $(n=120)$. Within a theoretical framework of belonging (Cohen, 1982) combined with Bourdieu's (1986) general theory of the economy of practices, the purpose is to shed light on three, interrelated questions: Why do young rural-urban migrants leave their places of birth, what do they leave behind, and do they consider moving back later in life? The new empirical contribution is to shed light on the latter, important question, which has been somewhat overlooked within rural studies. In line with previous studies, adolescents' decision to move was often complex, although achieving legitimate cultural (educational) capital in urban areas was crucial. However, most of them still felt a strong emotional attachment - belonging - to their local area, mainly to family, friends, local community and place. In what regards potential return migration, difficulties in getting a good job and thus securing good incomes and social recognition seemed to be the main obstacle for moving back. Hence, many seemed trapped between two 'competing' sets of emotions - security/warmth and personal pride/ambition - that is, between their belonging to a specific local field characterized by 'survival' networks (Corbett, 2013) and their longing for a non-specific, other place where they could achieve, and capitalize upon, highly state recognized forms of educational and symbolic capital targeted at the national 'field of fields' (cf. Hektner, 1995; Johnson et al., 2005; Bourdieu, 2014). At the macro level, the rural-to-urban migration trend mirrors an unequal distribution of legitimate symbolic capital in space, i.e. the rural-urban power divide, reinforced by a negative discourse of rurality (Winther and Svendsen, 2012).
\end{abstract}

Keywords: young rural-urban migrants, relocation motives, return migration, belonging, emotions, bourdieuconomics, forms of capital, rural Denmark, discourses of rurality

\section{INTRODUCTION}

\section{Young Rural-to-urban Migration}

Lemvig municipality in Denmark is categorized as one of the 16 most peripheral rural municipalities in Denmark. The municipality is known for its beautiful natural amenities and, due to its location at both sea and fjord, it markets itself as the land of wild sea water, fluffy hills and quiet fjord water (VisitNordjylland, 2017). Although rich on beautiful nature, cheap houses, peaceful surroundings and strong local communities, the municipality has suffered from a demographic decline during the last couple of decades. Thus, in 1993-2018 the 
decline amounts to $16,9 \%$, in comparison to the national average of the 16 so-called 'outskirt municipalities' of $7,4 \%$. In contrast, the average of all 98 Danish municipalities shows an increase of 11,6\% and, in the capital of Copenhagen, of 31,6\% during this period (Municipal Statistics, 2018). A major part of Lemvig outmigrants are young people who, as often, never return to their native places (Svendsen, 2013).

This mirrors an international trend of adolescents moving to urban centres in search for good jobs and educational possibilities, as reported from e.g. Australia (Argent and Walmsley, 2008; Gabriel, 2002), Uganda (Barratt, 2012) and Ethiopia (Bezu and Holden, 2014), the US (Hektner, 1995), UK (Jamieson, 2000; Giddings and Yarwood, 2005), Ireland (Ní Laoire, 2000, 2007); Scotland (Stockdale, 2002a, 2002b; Jones, 1999, Lumb, 1980), Estonia (Nugin, 2014), Norway (Wiborg, 2004), Sweden (Gustafsson, 2001), Iceland (Seyfrit et al., 2010), Poland (White, 2010), Russia (Eastman, 2013), China (Hu, 2012), as well as rural Europe in general (Champion, 2012).

On this background it is understandable that, in the Danish public debate, rural-to-urban migration has for long been seen as a growing problem (see e.g. Ministry of Housing, Urban and Rural Affairs, 2013; Christensen, 2017). This tendency has been reinforced by a municipal reform in 2007, reducing 270 municipalities into 98 and 13 counties into 5 regions and leading to centralization of many public services as primary schools (Svendsen and Sørensen, 2016) and hospitals (Danish Ministry of the Interior and Health, 2005). As a result, new terms have popped up in the debate, such as 'A and B Denmark', 'The skewed Denmark' (Det skave Danmark) and 'Broken Denmark' (Det knakkede Danmark). Likewise, we see an increasing popularity of negative terminology for rural Denmark, such as 'Outskirt-Denmark' (Udkantsdanmark), 'The peripheral areas' (Yderomraderne), 'Peripheral municipalities' (Yderkommuner) and 'The Rotten Banana' (Den rådne banan). Particularly, the term 'OutskirtDenmark' has become widespread in the Danish media from 2010 and onwards (Winther and Svendsen, 2012).

\section{The Choice between 'Old' and 'New' Forms of Capital}

A common trait in most of the abovementioned, international studies is that many adolescents have to make a difficult and often painful choice: Should they stay and invest their energy, money and life-time in building up resources in the local area, or should they do so at another place, often from scratch, and leave important resources behind? What however appears less obvious in the literature is that this in fact is a double choice for most outmigrating adolescents. Hence, after a certain period of time, they have to decide whether they should remain at the new place (or another place far from home) and use their achieved resources there, or return home to their native place and make use of them there.

In this paper, I will argue that these decisions and considerations best can be analysed by combining belonging (Cohen, 1985; Corbett, 2013) within a sociology of emotions (Barbalet, 1998; Bericat, 2016) with more rational or reasonable - investment strategies in forms of capital within economic sociology (Bourdieu, 1986; Waldstrøm and Svendsen, 2008). In all instances, however, emotions play a crucial role when understanding the adolescents' behaviour. Thus, the local setting is associated with a warmth and security that for the adolescents are difficult to 'sacrifice', while the extra-local setting is associated with opportunity of upwards social mobility and therefore feelings of ambition, personal pride, high self-esteem and social recognition that stretches beyond the local community.

Hence, translated into the capital theory framework (see also Section 3 for definitions), out-migrating adolescents are leaving behind forms of capital at their native place. These mainly consist in cultural and social capital in the form of useful and, within the local field, capitalizable local knowledge and local networks consisting of family, friends and connections. However, decisions of staying, leaving or returning do not only include considerations of leaving behind a stock of 'primary' or 'childhood' social capital, but also withdrawal from a specific community and place. Hence, the young outmigrant has to - fully or partially - give up a former identity based on attachment to a specific place and social group, something that may be hard to build up at another place. Therefore, building up new capital at the new place will as often imply costs - a trade-off the adolescents can barely escape.

In this way these young people become 'trapped' between two sets of 'competing' emotions, namely their need of warmth, security and predictability and their ambition to become successful in the eyes of the world. On the one hand stands their belonging to a specific socio-space characterized by rich and durable 'survival' networks (Corbett, 2013), where capitals are directed towards a local/regional field; on the other hand their longing for a nonspecific, other place where they can get a career and increase cultural, economic and (highly legitimate) symbolic capital that can be used in the national 'field of fields' (cf. Hektner, 1995; Johnson et al., 2005; Bourdieu, 2014).

Although a bit risky, one may expect talented youngsters to go to the big cities in order to accumulate, and harvest from, the most valued and, hence, most prestigious forms of capital - or mostly state legitimized, that is. Such state guaranteed capital can be immediately and universally applied within the field of fields, which by Bourdieu (2000: 240) is seen as "the central bank of symbolic capital", systematically attributing or not attributing social recognition to citizens and thereby maintaining relations of (apparent) necessity. As noted by Engler (2003: 6), the state here seems to take over "religion's pre-modern role as primary agent of consecration" by "legitimizing social 
distinction". And accumulating highly prestigious capital is indeed what many young people do. This allows them, ultimately, to harvest highly valued symbolic capital thanks to their educational capital, titles or, simply, urban dialects and manners - a kind of super symbolic capital. ${ }^{1}$ Hence, and as mentioned above, the adolescents' attraction to the urban metropoles rather than to a quiet country life has also something to do with a skewed power balance between the rural and urban population. Not surprisingly, such urban hegemony has led to negative discourses of rurality, further devaluing rural symbolic capital (Halfacree, 1995; Leyshon, 2008; Cruickshank et al., 2009; Winther and Svendsen, 2012; Corbett, 2013; Nilsson and Lundgren, 2015).2

\section{The Three Research Questions}

On this background the contribution is not only - in line with previous studies - to give an insight in Danish rural adolescents' relocation motives and their attachment to their birth place, but also try to understand their reasons for considering, or not considering, to return to their native place. Using the case of a Danish outskirt municipality, the purpose of this paper therefore becomes to shed light on the following three, closely interrelated questions:

\section{Why Do Young Rural-urban Migrants Leave Their Places of Birth, What Do They Leave Behind, and Do They Consider Moving Back Later in Life?}

Apart from the combined Belonging and 'Bourdieuconomics' approach (sociology of emotions 'married' to economic sociology), the new empirical contribution is to shed light on the latter, important question, which has been rather overlooked within rural studies. Results are reported from two studies in the municipality of Lemvig, namely a 2011-survey study comprising 120 outmigrants, and a telephone interview study in November 2012 with 25 young, arbitrarily chosen outmigrants between $20-27$ years of age.

\section{Outline}

After the literature review in Section 2, definitions of theoretical key concepts are presented in Section 3. The study design is further described in Section 4. Section 5 presents main results from the survey. Results from the interviews are then presented in Section 6, leading to a model figure that summarizes the main findings. Finally, Section 7 concludes.

\section{LITERATURE REVIEW: YOUNG RURAL-TO-URBAN MIGRANTS}

As mentioned, the literature clearly shows that the concentration of young people in urban areas is a megatrend. Moreover, studies show that most rural adolescents carry with them an attachment to their native place, even though they do not choose to live there (e.g. Glendinning et al., 2008; Leyshon, 2008). This sense of belonging (Cohen, 1982, 1985) often consists of a combination of place attachment and social belonging (Pollini, 2005). In Denmark, several rural-to-urban migration studies have been done (e.g. Svendsen, 2003; Thuesen, 2012; Nørgaard, 2012). However, to my knowledge my study is the first one that focuses on young rural-to-urban migrants' relocation motives and their considerations about moving back.

To get a sense of the magnitude of the problem, I will first briefly review a couple of studies that have investigated consequences of youth migration for local communities, followed by a review of studies of rural adolescents' relocation choices or, more specifically, their dilemma between belonging and longing.

\section{The Flight of the Young: Overall Consequences for the Communities}

In a more overall perspective, outmigration of adolescents has serious impact on rural communities. For example, a study from Australia (Argent and Walmsley, 2008) sheds light on the consequences for local social networks. Using demographic data from 1976 to 2001, it analyses recent trends in youth (15 to 24 of age) rural-tourban migration. Combined with a review of existing literature on the Australian case, it finds that huge outmigration among rural adolescents have severe social consequences for the single communities in the form of disruption of local bonds and, hence, social capital being destroyed. This leaves these communities in a vicious circle with dying associational life, economic decline, drain of women and, overall, social fragmentation and isolation (op.cit.: 148).

\footnotetext{
${ }^{1}$ It seems that the trend is that symbolic capital becomes increasingly connected to urban centres all over the world to the degree that a citizen living in a remote area, as a result of symbolic violence, would be ashamed of admitting to strangers his or her postal code.

2 A tendency that can be found in Australia as well (Gabriel, 2002) and, probably, in many other countries as well. This discoursive impact on rural-urban relocation patterns has also been explored by Halfacree, who talks about the importance of the "social representation of the rural", including amenities, relaxation and rich social life - a representation that is as often superseded by discourses celebrating urban life. He also points to Ray Pahl's term "village-in-the-mind" in promoting migration to rural areas - something that an 'anti-rural' discourse might wipe out of people's and/or youngsters' heads (Halfacree, 1994: 184, 185).
} 
An example of huge rural-urban exodus can be found in Iceland. In 2007, 70\% of all rural adolescents wished to leave their home communities, while only $30 \%$ of urban youth in the only urban area of capital Reykjavik wanted to migrate (Seyfrit et al., 2010: 1211). As in the Australian case, rural areas tend to end up in a wicked circle, with loss of jobs and "female flight" (op.cit.: 1212). Furthermore, the study shows that decentralization in the form of the establishment of a large aluminium and hydroelectric plant in a sparsely populated rural area, as part of a regional development policy of getting more jobs to rural areas, did not significantly contribute to counter-act migration of rural youth.

Recently, such processes have been described as shocks that threaten the resilience of the local community (Wilson, 2012). Hence, depopulation may lead to extinction or renewal, understood as change into a new social system that is more socio-economically sustainable.

\section{The Dilemma between Belonging and Longing}

\section{Belonging}

As mentioned above, many studies show that modern young people find themselves in a dilemma between emotional attachment to their home place (belonging) and a wish to have careers outside the local community (longing).

Cohen's (1982) classical study based on ethnographic fieldwork in six local communities in the island of Whalsay, the largest of the Shetland islands in Scotland, shows that rural communities are demarcated symbolically by e.g. body language, dialect and culturally specific jokes, forging strong local identities. They feel a belonging, in opposition to hegemonic identities (such as English), to which locals - including many young people - feel alienated and, besides, from which they actively try to distance themselves symbolically and in practice.

According to Cohen, the sense of belonging to a community and having a community identity is transcultural and transhistorical, that is, not only belonging to 'traditional' non-western societies. It roots in a continuous "boundary maintenance", where the symbolical construction of group boundaries "creates a sense of belonging, of identity - and, by the same token, of difference from others" (Cohen, 1985: 53).

\section{Longing}

Compared with Cohen's study, the dilemma between belonging and career is much more dominant in Hektner's (1995) survey study from three midwestern school districts in the US ( $n=918)$. In the literature, she finds that the main explanation of why rural adolescents leave is an ambition of upward mobility, however many only make this decision reluctantly (op.cit.: 4). Adolescents do not leave due to strong family and community ties, while many of those with strong place attachment, who leave nevertheless, continue to feel a psychological bond with their home community (ibid.). Her own survey also shows that, among adolescents, an inner struggle is taking place between their inclination to "pursue educational and career goals" and "living close to family" in the local community (op.cit.: 11). The two wishes are described as "two mutually incompatible wishes", something that may lead to anger, not least among adolescent males (op.cit.: 12). Basically, the choice is between "moving up" socioeconomically or lowering educational and career ambitions. In this sense, "moving up" will imply "moving out" (op.cit.: 3,5$){ }^{3}$

Using data from the Australian Bureau of Statistics, interviews, focus groups and surveys, Alston (2004) finds that the loss of adolescents in Australian rural communities - and the particularly great loss of young women - is due to push effects such as fewer full-time jobs, especially within the agricultural sector, combined with a shrinking public sector in these areas and that many youngsters find that 'nothing ever happens'. Together with the wish of further education (pull effect), this contributes to drive youngsters away from their native places, often meaning the "death of country towns" (op.cit.: 303). Many young outmigrants were however still strongly attached to their native places, revealed in statements like "'I know it's a bit of a bumphole, but it's just good!", "This is my home. [But] you don't want to be a checkout chick all your life" and "It's like the next step - you leave school, you go away" (ibid.). Youngsters who did not out-migrate tended to be more vulnerably, risking unemployment and social déroute (op.cit.: 310). Alston concludes that providing "real options for rural young people is one of the most effective areas in which to start this support [of rural revitalization]" (op.cit.: 311).

Providing real options for rural young people is one of the most effective areas in which to start this support.

The dilemma is also confirmed in several other, recent studies. For example, a study based on 50 interviews with Norwegian university students reveals that many adolescents born in rural communities feel a strong attachment to "factors such as nature, kinship, social class and lifestyle" (Wiborg, 2004: 429).

\footnotetext{
${ }^{3}$ In this context, Hektner mentions Sargiani et al. (1990) who find that - seen from the perspective of the leaver - "the positive wish to stay in the community with family and friends may also become a negative pressure for those who must leave to attain their goals" (Sargiani et al., 1990 cited in Hektner, 1995: 3). Hence, strong local ties can become a hindrance for careers.
} 
Jamieson (2000) conducted 45 interviews with young people in the border region between Scotland and England and found strong attachment to the home area, however dependent on social class. That this attachment roots back in early childhood is shown in a survey study $(n=4100)$ including rural adolescents from Scotland, Norway and Sweden (Kloep et al., 2003). It reveals that stayers have the lowest academic ambitions, however at the same time they hold the lowest mean depression scores (Kloep et al., 2003: 106). This confirms other studies showing that generally, in EU countries, life satisfaction is not lower among the rural population, in fact slightly higher (Sørensen, 2014). Furthermore, in the Kloep et al. (2003) study, 80\% of the sample consisted of stayers and returners, who generally had positive perceptions of rural life and felt themselves well integrated in local communities. Only 20\% hated rural life and never would choose to live their lives in their rural native places.

Similar to the abovementioned studies, Stockdale's (2002a) study of outmigration from rural Scotland describes rural youth in a dilemma, however few adolescents here have problems with deciding whether to stay or leave. This is due to "the expectation that they would one day leave their home community" (op.cit.: 60). Further key findings from this study that comprises 212 survey respondents and 25 qualitative interviews are that rural adolescents primarily leave for educational and employment reasons, that family and social networks have importance for choice of first destination with students on the whole "following the herd", outmigrants regularly meet with others from their home areas and, finally, the importance of family and social networks tends to gradually decline (op.cit.: 61). ${ }^{4}$

To sum up, we see that most adolescents leave their communities, at least the most resourceful, due to ambitions of achieving cultural (educational) capital and economic capital, that is, good incomes due to educations/forms of knowledge that are highly recognised and valued by the state. They however most often do so reluctantly, knowing that they will lose valuable 'local' social capital, in the form of friends and family, and perhaps also, by them highly valued nature assets. In a way, they have to sacrifice their belonging to a community for the longing for upward social mobility - something that also becomes evident in my study.

\section{THEORY}

\section{Making Careers: Achieving Forms of State Legitimized Capital}

\section{A General Science of the Economy of Practices}

How do people mobilize resources in order to make a career? Within recent economic sociology, scholars have increasingly conceptualized this as people's ability to cultivate, build up and apply forms of capital (Coleman, 1994; Swedberg, 2011). This is in line with Bourdieu's (1979a, 1979b, 1986) seminal idea of a "general science of the economy of practices". This framework has also been used within rural studies (see e.g. Svendsen and Sørensen, 2007; Bosworth and Turner, 2018) and is relevant in the study of young out-migrants by directing focus towards which forms of capital these adolescents value mostly, in an explanation of why they move and whether they consider turning back.

The capital theory - by some termed Bourdieuconomics (Svendsen and Svendsen, 2003) - points at the existence of both material and immaterial forms of capital (economic, cultural, social, symbolic), i.e. accumulated human labour that is transferred through history in things or bodies (Bourdieu, 1986: 241). Unlike what economists previously have done, these forms of capital should be analysed at the same level and not, for example, prioritizing/separating economic above/from cultural, social and symbolic. Similar to Polanyi's (1977) ideas that forms of economic integration - reciprocity, market exchange and redistribution - should be studied in a holistic approach as dynamic, time-space dependent and, at the same time, universal configurations, Bourdieu's vision was to "grasp capital and profit in all their forms and to establish the laws whereby the different types of capital (or power, which amounts to the same thing) change into one another" (Bourdieu, 1986: 243).

\section{Field and 'Field of Fields'}

Of course, capital does not exist in a vacuum. Rather, the forms of capital are only applicable within specific fields at the micro and macro level (e.g. political, juridical, literary, scientific, a field consisting of a business sector etc.), each following their own specific logics.

Bourdieu proposes an analytical definition of field as "a network, or configuration, of objective relations between positions objectively defined, in their existence and in the determinations they impose upon their occupants, agents or institutions, by their present and potential situation (situs) in the structure of the distribution of power (or capital) whose possession commands access to the specific profits that are at stake in the field, as well

\footnotetext{
${ }^{4}$ Stockdale's findings are in line with a previous study on young Scottish outmigrants. Jones (1999) reports on similar findings, however she stresses the impact of socialization and individual biographies. This approach can also be found in an Irish study, where conclusions are that motivations lying behind the decision to move away are complex and closely interlinked with a person's life biography and what is socially accepted in a local community (Ni Laoire, 2007).
} 
as their objective relation to other positions" (Bourdieu and Wacquant, 1992: 72). Hence, individual and group habituses are systematically linked to specific positions in fields in specific time-space contexts, enabling agents to act 'naturally' in accordance with the taken-for-given field rules (doxa), as well as negotiating, opposing and/or transforming these rules, and those individuals or organizations holding the largest amount of legitimate, fieldspecific capital being the most powerful agents. In this sense, "a capital does not exist and function except in relation to a field. It confers a power over the field" (Bourdieu and Wacquant, 2007: 101).

At the most general level, Bourdieu talks about the state as a complex field of fields, also termed a "field of power" (Bourdieu and Wacquant, 1992: 56). Prevailingly a nation state, or field of fields, is governed by the political and economic fields and sub-fields and, as mentioned in the introduction, governing social distinction by, in the wordings of Bob Jessop (2015: 33), operating as "the central bank of symbolic capital' in organizing other social fields, such as housing, education, marriage, public opinion, law and the professions". ${ }^{5}$

When analyzing migration patterns among adolescents, it becomes relevant to include the local fields, that is, the local communities to which most adolescents feel a belonging; as well as the field of fields in the form of the state of Denmark. In this case, the state ostensibly operates as 'the central bank of symbolic capital' by guaranteeing the young outmigrants to the big cities - and especially those going to the universities - what I term 'super' symbolic capital, enabling them to fulfill their career ambitions (longing) and achieve universal social recognition. In the following, I will shortly define the forms of capital pertaining to a field.

\section{Profits: Economic, Cultural, Social and Symbolic Capital}

According to Bourdieu, the mutually convertible forms consist of three "fundamental disguises of capital", namely economic, cultural and social (op.cit.: 243). If recognized within a field as legitimate, all three simultaneously function as symbolic capital, i.e., social recognition (prestige) and, hence, "legitimate competence" within this field (op.cit.: 245). However, at the same time symbolic capital functions to dissimulate power relations ("labor of dissimulation"), that is, euphemization and denial of economic interests (op.cit.: 243). Hence, symbolic capital should also be seen as a capital form per se. For example, due to historical socioeconomic conditions and discoursive effects, urban identities are today automatically associated with high symbolic capital (power) compared with rural identities as, e.g., revealed in postal codes.

In what regards profits, economic capital will be defined as money or money like resources (e.g. stocks and bonds), that is, the most liquid and 'crude' form of capital, which - in certain time-space contexts - can be directly convertible to social recognition, i.e. symbolic capital (as is, for example, revealed in many novels, for example Dostoyevsky's marvellous book, The Gambler).

Cultural capital will be understood in Bourdieu's (op.cit.: 243-244) three-fold way, namely as consisting of invisible, permanent dispositions in the individual person, or habitus (embodied state), of humanly created objects such as books, instruments and machines (objectified state), and as educational qualifications such as academic degrees (institutionalised state). I will however only apply two sub-types of embodied cultural capital, namely educational capital, i.e. formal education (cf. economists' human capital), and 'primary cultural capital', i.e. knowledge, norms, ways of behaviour learned informally through childhood and early adolescence.

Finally, by social capital is understood "the aggregate of the actual or potential resources which are linked to (...) membership in a group (...) which provides each of its members with the backing of the collectively-owned capital, a "credential" which entitles them to credit, in the various senses of the word" (op.cit.: 248-249). Thus, social capital can be seen as a kind of master capital giving access to other people's resources and, thusly, multiplying a person's resourcefulness (for example a politician or a leader of a big company). Besides, power based on social capital tend to increase if, in the wordings of Burt (1992), social connections are diverse, non-redundant (in relation to career ambitions) and resourceful, and if the person in question finds himself/herself in powerful positions between resourceful networks (structural holes).

\section{Feeling Accepted: Belonging}

How do people fulfil their need to feel socially accepted? This dimension must also be included in order to properly understand rural adolescents' location choices. The interviews indicate that they become very emotional when talking about their places of birth, including nature, friends and family and the local community. As argued by Barbalet (1998: 9) "emotion can be regarded as an outcome or effect of social processes [and is] in principle amenable to sociological examination and explanation". In this perspective, emotion should be seen as a "social cause" that is necessary to include when explaining "the very fundamentals of social behavior" (ibid.). Hence, the individual (rational) decision process cannot be separated from emotional motivations and effects.

\footnotetext{
5 "At some point, he [Bourdieu] called it the "central bank" of universally accepted circulating "fiduciary" powers or values which, under those characters of officialdom and universality, are presented with the attributes of "divinity" or "nature", and endows the political activity that founds them with the attributes of a "civil religion"”' (Baños, 2017: 2).
} 


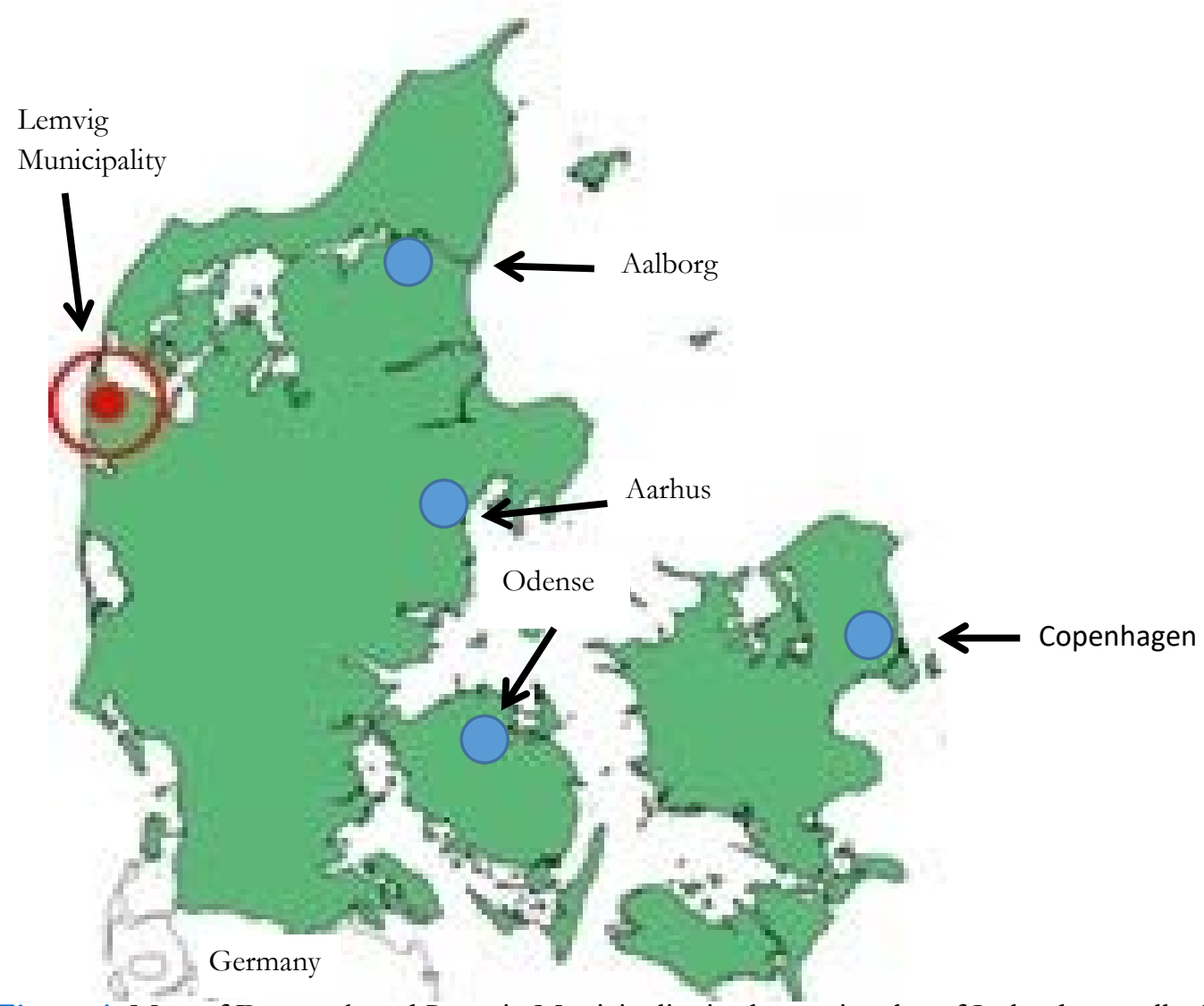

Figure 1. Map of Denmark and Lemvig Municipality in the peninsular of Jutland, as well of the four largest cities in Denmark

This is closely related to a more recent research strands like studies within "emotional intelligence" (Goleman, 1996) and "emotional capital" (for a review, see Cottingham, 2016). The latter has, within the Bourdieusian capital framework, been defined as an embodied type of cultural capital, which denotes "one's trans-situational, emotionbased knowledge, emotion management skills, and feeling capacities, which are both socially emergent and critical to the maintenance of power" (Cottingham, 2016: 454). Hence, emotions can be seen as productive, not least in our work life, as illustrated by the daily practices of nurses, reflecting Bourdieu's notion of "feel for the game" (op.cit.: 466).

As already argued, in our rural local community context the emotional motivations of young outmigrants can appropriately be summed up in the term belonging, which links emotions to social and place attachment. It is here defined in accordance with Cohen (1985: 53) as the symbolical construction of group boundaries, which create "a sense of belonging, of identity - and, by the same token, of difference from others". In other words, identity is construed in the perceived differences between, for example, rural and urban identities (dialect, body language, norms and values, humour, mentality), something that also became evident in my interview study.

This relativist and constructivist stance somewhat parallels Bourdieu's notions of habitus and group habitus as well as the concept of emotional capital. However, unlike these concepts that are often linked to social class and work practices, "belonging" is directed to a specific understanding of an individual's emotional attachment to a specific local community and place rooted in an identity position, which makes the individual capable of perceiving contrasting (competing) identities. The emotional content of belonging should here be seen as an effect of social processes in line with Barbalet, rooted in experiences during childhood and early youth. Moreover, in this light the adolescents' career ambitions should not be seen as purely 'rational', but likewise driven by emotions like personal pride and a wish for a social recognition that reaches outside the local community.

In the following, Bourdieusian capital theory on the one hand is used to account for the 'profits' (in the broad sense of the word) that the adolescents hope to achieve by leaving, and where decision-making is closely connected to feelings of pride and extra-local recognition; and on the other hand Cohen's concept of belonging to assess the significance of their, due to primary cultural capital, attachment to a specific local community and region, including their wish to return. 
Table 1. Telephone interviews with young outmigrants from Lemvig Municipality, Denmark, November 2012. List of interview persons

\begin{tabular}{|c|c|c|c|c|c|c|}
\hline $\begin{array}{l}\text { Number/ } \\
\text { Pseudonym }\end{array}$ & Gender & Age & $\begin{array}{c}\text { Born in the } \\
\text { Municipality? }\end{array}$ & $\begin{array}{c}\text { Employment/ } \\
\text { Study }\end{array}$ & New domicile & $\begin{array}{l}\text { Remote- } \\
\text { Near* }\end{array}$ \\
\hline 1. Mie & $\mathrm{F}$ & 23 & Yes & University student & Aarhus & Remote \\
\hline 2. Majken & $\mathrm{F}$ & 23 & Yes & University student & Aarhus & Remote \\
\hline 3. Nikolaj & $\mathrm{M}$ & 23 & Yes & University student & Aarhus & Remote \\
\hline 4. Flemming & $\mathrm{M}$ & 23 & Yes & University student & Aarhus & Remote \\
\hline 5. Kenneth & $\mathrm{M}$ & 25 & Yes & University student & Aarhus & Remote \\
\hline 6. Morten & $\mathrm{M}$ & 24 & Yes & University student & Aarhus & Remote \\
\hline 7. Anders & $\mathrm{M}$ & 23 & Yes & University student & Aarhus & Remote \\
\hline 8. Signe & $\mathrm{F}$ & 23 & Yes & University student & Aalborg & Remote \\
\hline 9. Majbritt & $\mathrm{F}$ & 25 & Yes & University student & Copenhagen & Remote \\
\hline 10. Cecilie & $\mathrm{F}$ & 25 & Yes & Nurse student & Aarhus & Remote \\
\hline 11. Nicoline & $\mathrm{F}$ & 23 & Yes & Physiotherapist student & Aarhus & Remote \\
\hline 12. Stine & $\mathrm{F}$ & 24 & No & Air traffic controller student & Aarhus & Remote \\
\hline 13. Sabrina & $\mathrm{F}$ & 22 & Yes & Business school & Aalborg & Remote \\
\hline 14. Silas & $\mathrm{M}$ & 24 & $\mathrm{No}$ & Kindergarten teacher student & Køge & Remote \\
\hline 15. Martin & $\mathrm{M}$ & 22 & Yes & Smith & Holstebro & Near \\
\hline 16. Lasse & $\mathrm{M}$ & 25 & Yes & Smith & Buur & Near \\
\hline 17. Paul & $\mathrm{M}$ & 23 & Yes & Carpenter & Sønder Rind (near) & Near \\
\hline 18. Jacob & $\mathrm{M}$ & 25 & Yes & Carpenter & Holstebro & Near \\
\hline 19. Tobias & $\mathrm{M}$ & 23 & Yes & Carpenter & Holstebro & Near \\
\hline 20. Laura & $\mathrm{F}$ & 22 & Yes & Professional bachelor student & Thyholm & Near \\
\hline 21. Benjamin & M & 20 & Yes & High school student & Holstebro & Near \\
\hline 22. Jesper & M & 22 & No & Translator student & Struer & Near \\
\hline 23. Helena & $\mathrm{F}$ & 20 & No & Unemployed & Favrskov & Near \\
\hline 24. Sara & $\mathrm{F}$ & 25 & No & Unemployed & Ringkøbing & Near \\
\hline 25. Palle & $\mathrm{M}$ & 27 & No & Unemployed & Holstebro & Near \\
\hline
\end{tabular}

* "Near" means a close-by and, in most cases, neighbouring municipality; "Remote" means a municipality far from Lemvig Municipality, all larger university cities (except from Køge).

\section{STUDY DESIGN}

Similar to Stockdale's (2002) study, I have combined a questionnaire survey with a follow-up interview study (telephone interviews) in the municipality of Lemvig in the western part of peninsular Jutland. This is a part of Denmark that is characterized by small population density, few public services and quite bad infrastructure compared with most other regions in Denmark (Figure 1).

\section{Questionnaire Survey}

The survey sheds light on why the adolescents leave, as well as what they appreciate in the place where they grew up (most of them being born there as well). The questionnaire was developed jointly by employees at Lemvig Municipality and the author.

The survey was conducted as telephone interviews by a consultancy firm in May 2011 and included migrants who had moved out of the municipality during a period of two years. 120 valid responses were collected. The average age of outmigrants was slightly over 33 years, and the two largest groups were those between 19-24 (44\% of the total number) and those between $25-35$ (29\% of the total number). Thus, near 3 out of 4 outmigrants were young people between 19 and 35, most of them born and grown up in the municipality.

What regards representativeness, the 120 outmigrants constitute near $14 \%$ of the average of the total number of relocations $2009-11 .{ }^{6}$ In the following, I will restrict myself to show the results of the two open questions that were relevant to the first research question.

\section{Interviews with Young Rural Outmigrants}

The purpose of the 25 interviews with randomly chosen outmigrants between 20-27 years of age was to shed light on both why they have left and whether they considered returning home. The average age was 23,4. Among the 25, there were 14 male interview persons (Table 1).

${ }^{6}$ It may be added that the sample is relatively representative regarding to both age and gender. Thus, the average number of outmigrants 2006-12 in the 19-24 age group was 39\%, compared to 44\% in the sample. There is, however, a slight overrepresentation in the 25-35 group. There is a fairly equal share of males and females. Concerning education, most of the respondents have a general secondary education (37\%) or are under secondary education (43\%). One third grew up in the municipality. Almost 4 out of 10 were living with a partner and only $10 \%$ had children. 


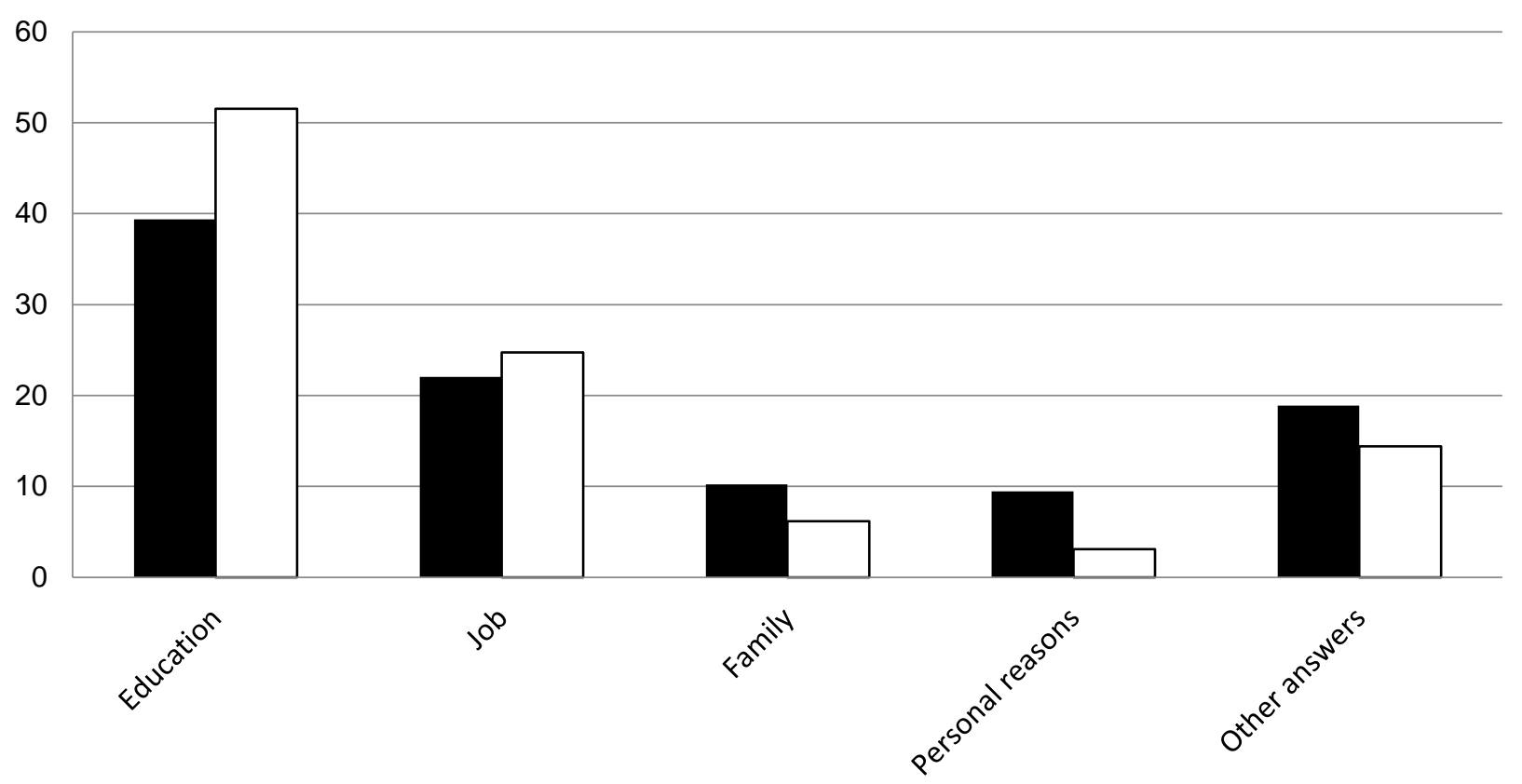

\section{- All respondents $\quad \square$ Respondents of 19-35 years of age}

Figure 2. "What is the main reason why you moved to another municipality?" Percentage distribution of 127 answers from 120 outmigrants and 97 answers from 88 outmigrants of 19-35 years of age, 2011

The interviewees can be divided into 'remote' and 'near' outmigrants. The near outmigrants are the 11 adolescents who have moved to municipalities within the region (often neighbouring municipalities), which also means municipalities with no major urban centres. 13 of the 14 remote outmigrants are adolescents who have moved to large cities as Aarhus, Aalborg and Copenhagen in order to study, among them 9 are university students, see Table 1.

Although I did not ask them about their family backgrounds, my clear feeling was that they belonged to different social classes - something I also noted in my diary. ${ }^{7}$ Thus, in line with the findings in Hektner (1995), Jones (1999), Stockdale (2002a) and Ni Laoire (2007) there were many signs indicating that the remote migrants with the most ambitious educational aspirations came from the most resourceful families, as e.g. expressed in sophisticated language, self-reflection, career considerations and ambitions, long term planning, long, eloquent answers, way of speaking, happy memories from their childhood, positive experience with school and high school, trustfulness, strong social networks and, overall, an optimistic world view, mental surplus and high self-esteem/self-assurance. This stood in contrast to the interviews with the near migrants, who exhibited much less enthusiasm (often even shamefulness) and a less optimistic world view, gave short, somewhat crude answers (often with low, husky voices), were more prejudiced and talked with a more pronounced regional dialect.

The interviews showed that these interviewees to a large extent are members of Lemvig networks - similar to the 'native' social networks in Scotland described by Stockdale (2002). Out of the 11 near outmigrants, we find 5 craftsmen, 3 who undertake short/medium length education, while 3 are unemployed. Besides having less educational ambitions, no near migrants were members of Lemvig networks in their new municipality.

All 25 follow-up interviews were conducted in November 2012 with interview guide. These semi-structured interviews lasted 20-30 minutes and were all transcribed. Lists of outmigrants were delivered from Lemvig Municipality. As a tool for analysing the interviews, the software program NVivo was used.

\footnotetext{
${ }^{7}$ For example, I wrote on November 11, 2012: "I have noticed that the young students in Aarhus and Copenhagen are easier to access that the youngsters in the nearby area (Holstebro, Struer, Skjern etc.), moreover that they generally are more trusting, eloquent and reflective. Differences in social class? Differences in life styles? Besides, the majority of students [remote outmigrants] stress that those who are 'left back' in the municipality have another life style or, rather, life form - something like spouse, children, orientated towards local issues. The students want something more with their lives."
} 


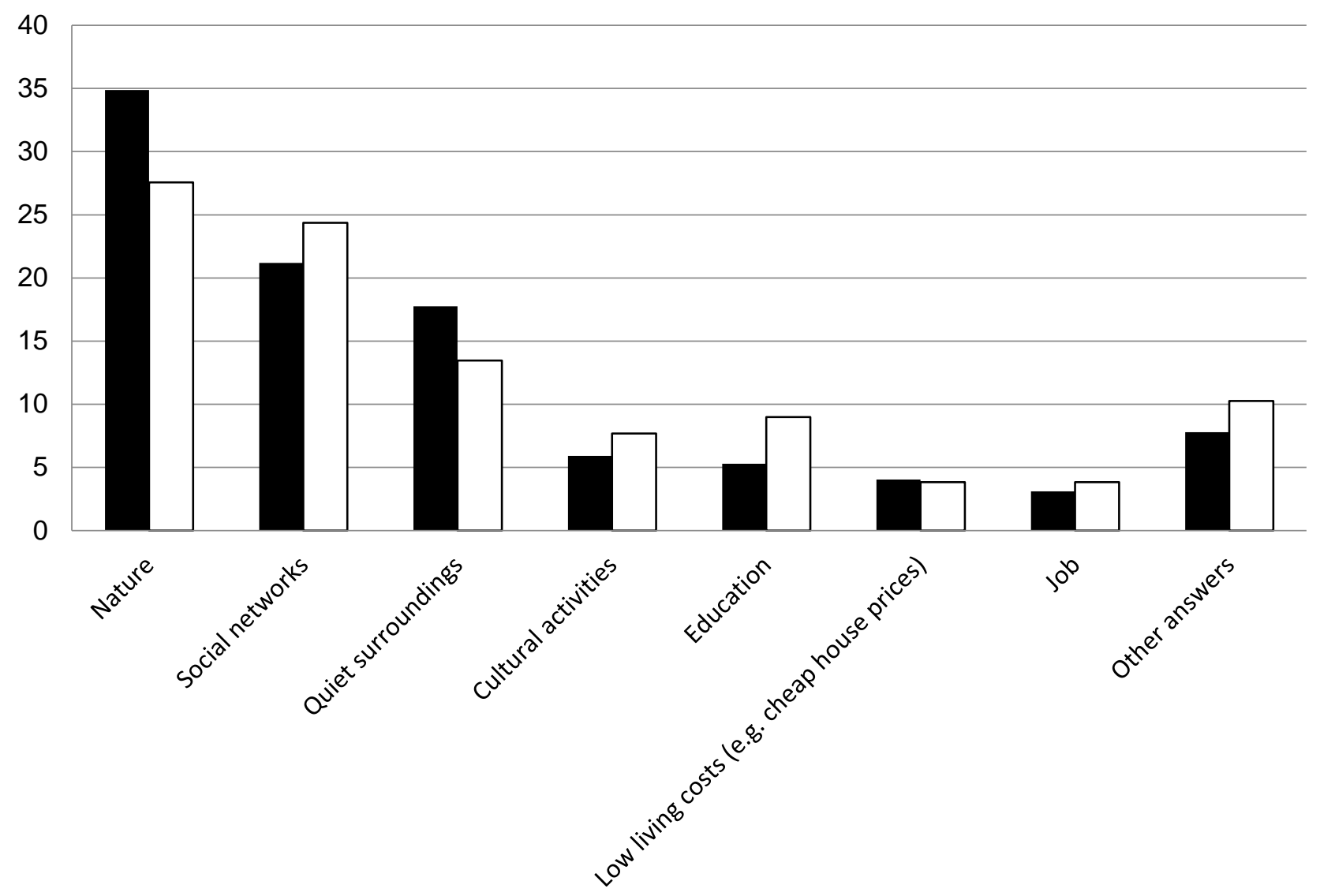

- All respondents $\quad \square$ Respondents of 19-35 years of age

Figure 3. "What did you find most attractive in Lemvig Municipality?" Percentage distribution of 321 answers from all 120 outmigrants (total sample) compared with 156 responses from 88 outmigrants of 19-35 years of age, 2011

\section{QUESTIONNAIRE SURVEY}

\section{Reasons for Outmigration: Educational and Economic Capital}

Figure 2 shows the answers to an open question about what made people move out of the municipality. The answers were afterwards categorized by the author. We see that a little more than $60 \%$ of all answers were distributed on education and work. Moreover, when only selecting the 88 respondents within the 19-35 age group, educational reasons increased to $52 \%$ and job reasons to $25 \%$.

Hence, cultural (educational) capital was sought for - not least by adolescent outmigrants - together with jobs and, presumably, improved incomes, that is, economic capital. Social capital, however, in the form of "family" and "personal relations" only played a minor role.

\section{Rural Attractions: Social Capital and Nature}

Overall, the survey showed that the 88 young migrants between 19-35 years did not feel bad in their previous municipality. Thus, to the question "To which degree did you feel settled down in Lemvig munipality?", a little more than $90 \%$ answered that they had felt settled down well, while the remaining $10 \%$ did not.

Also the youngsters did not find Lemvig Municipality devoid of attractions. Here Figure 3 shows that it is primarily "nature", "social networks" (friends, family, acquaintances) and "quiet surroundings" that all 120 outmigrants see as the most important attractions in the municipality. As can be seen, the 88 young outmigrants in the sample are a little bit less appreciative of the municipality's "nature" and "quiet surroundings" (place amenities), but more appreciative of "social networks", "Education" and "Cultural activities", although the latter two categories generally obtained low scores. Also notice that "Job" achieved the lowest score, about 3 percent. 
Table 2. Answers from interviews with 25 young outmigrants, divided into 18 main categories, in total 565 words. November 2012. NVivo count

\begin{tabular}{|c|c|c|c|c|}
\hline No. & Category & Quality & Number & $\%$ \\
\hline 1 & Negative mentioning of rural life & Negative & 88 & 15,6 \\
\hline 2 & Friends & Positive & 83 & 14,7 \\
\hline 3 & Family, home and childhood & Positive & 81 & 14,3 \\
\hline 4 & Primary school and college & Negative and positive & 50 & 8,8 \\
\hline 5 & Job opportunities in Lemvig Municipality & Negative & 38 & 6,7 \\
\hline 6 & Educational opportunities in Lemvig Municipality & Negative and positive & 38 & 6,7 \\
\hline 7 & Nature in Lemvig Municipality & Positive & 32 & 5,7 \\
\hline 8 & Quiet and secure environment in Lemvig Municipality & Positive & 22 & 3,9 \\
\hline 9 & Local communities and neighbours in Lemvig Municipality & Positive & 22 & 3,9 \\
\hline 10 & Regional cultural identity & Positive & 18 & 3,2 \\
\hline 11 & Public transport in Lemvig Municipality & Negative & 17 & 3,0 \\
\hline 12 & Sports activities in Lemvig Municipality & Negative and positive & 17 & 3,0 \\
\hline 13 & Cultural activities in Lemvig Municipality & Negative and positive & 17 & 3,0 \\
\hline 14 & Health service Lemvig Municipality & Negative & 13 & 2,3 \\
\hline 15 & Housing & Positive & 12 & 2,1 \\
\hline 16 & Western Jutland & Positive & 11 & 1,9 \\
\hline 17 & Lemvig town & Positive & 3 & 0,5 \\
\hline \multirow[t]{2}{*}{18} & Negative mentioning of city life & Negative & 3 & 0,5 \\
\hline & In total & & 565 & 99,8 \\
\hline
\end{tabular}

Hence, the comparative advantages of a rural area such as Lemvig Municipality seem to be natural amenities as well as strong local communities, rich on dense social networks. Concerning adolescent outmigrants, the overall pattern is that they go for educational and economic capital and skip 'primary social capital' in their native places. However, they still feel strongly attached to these areas in terms of social attachment and, not least, place attachment.

\section{INTERVIEWS}

In the following I will try to shed further light on young outmigrants' moving decisions, what they think they have left behind, and whether they consider moving back.

\section{Content Analysis: Still Strong Belonging}

To find out what the interviewees mostly spoke about, I have reviewed all the key words in the interviews and categorized them. I have also assessed each category as predominantly positive or negative towards life in a rural municipality as Lemvig, something which might also be impacted by the rather negative discourse of the rural areas in Danish public media in recent years (Winther and Svendsen 2012). Table 2 shows the results.

As can be seen, top scorer is "negative mentioning of rural life" (more than $15 \%$ of all answers), that is, remarks that life here is dull, nothing happens, there are no opportunities here, etc. However, in top 10 then follow prevailingly positively loaded words about "friends" (near 15\%) as well as "family, home and childhood" (14\%). Then follows "primary school and high school" (near $9 \%$, with a mix of positive and negative words), lack of "job opportunities" in a negative sense (near 7\%), "educational opportunities" (near 7\%, mix of positive and negative words), followed by positive words about "nature" (near 6\%), "quiet and secure environment" (near 4\%), "local communities" (near 4\%) and the "regional, cultural identity", often expressed as the regional (western Jutland) mentality (little more than 3\%).

The count of positively and negatively loaded words within 18 main categories makes it possible to form an overall picture of which perceptions these adolescents (and potential return migrants) have of life in the municipality. It turns out that $28 \%$ of all words, distributed on 5 categories, are prevailingly negative. However, despite negative national media coverage, $50 \%$ of all words, distributed on 9 categories, are prevailingly positive. This indicates a (still) strong social and place attachment and 'primary (childhood) social capital'. Finally, the last 22\% distributed on 4 categories contain both positively and negatively loaded words. In total, this indicates a fairly positive picture of the municipality/home area and, hence, a potential for return migration.

\section{Longing: Reasons to Move}

Not surprisingly, education was mentioned most often (15 times), followed by friends (9), lack of opportunities (7), to get away from home (5), due to the person disliking the municipality (3), due to job (2) and other responses (6).

\footnotetext{
8 This category also includes girlfriends/boyfriends.
} 


\section{Educational Capital}

Concerning education, a typical answer came from a 23-year old engineering student in Aarhus, Anders: "Due to education, that's the most important". Anders grew up in Bøvling, a small, close knit local community in the municipality, which he still holds dear and is emotionally attached to. However, all his friends have also moved to Aarhus, and now he is meeting with them regularly there. Besides, a couple of interviewees said that they could not get the education they wanted in their home municipality, that is, in this case a push factor.

\section{Social Capital in the 'Luggage': The Lemvig Colonies}

Second to education, friends were mentioned as a major driver. This not least included the Aarhus 'colonies', that is, the Lemvig adolescents forming social networks in this city (see Figure 1). In fact, 10 out of 14 'remote' migrants had become students in Aarhus. This clearly reflects the dominant trend among the Lemvig adolescents who have ambitions of undertaking higher education - in contrast to the seemingly less ambitious and/or resourceful young people who either have remained in the municipality (as was indicated by some of the interviewees) or have moved to neighbouring municipalities where they can find jobs without higher education. Hence, it may not be a coincidence that 3 out of 11 'near' migrants were unemployed at the time of the interview.

As the interviews progressed, it became more and more clear that the 'immigrant networks' of Lemvig adolescents in Copenhagen, Aalborg and - not least - Aarhus were extremely important pull factors for new young outmigrants from Lemvig Municipality. It also became clear that these networks both had important social and economic functions. Thus, the adolescents are simply 'bringing' their social capital with them to the big university cities, not least friends from childhood and/or high school. This is to say that they start their life here without parents, but not from scratch, because very often they bring their oldest and closest friends with them.

\section{No Opportunities to Build up Prestigious Capital}

There were also several who would in any case had moved, because they thought there was "too little going on in the municipality" - something that, similar to lack of educational and job opportunities, pushed the young people out of the municipality. That there were too few opportunities for young people in their twenties was a recurring theme in the interviews. This also applies to cultural events. The abovementioned Anders explained: "There is not much for young people to do out there. There are not so many new initiatives, such as concerts. There are not many incentives for young people [to stay there]". Another outmigrant, Flemming, who studied business economics at Aarhus University, and who was born and raised in the small village of Nissum, put it this way: "I wanted to live in a city to get a few more options. I was a little bit tired of the lack of opportunities shopping and opportunities to meet new people".

9 of the 14 'remote' outmigrants mentioned at one point in the interview the lack of opportunities, while this only was the case with 4 of the 11 'near' migrants. Hence, the tendency seemed to be that the most ambitious adolescents were in search for 'opportunities' (in the broad sense of the word) far away from home - a longing that appears much stronger than their belonging. This was not least the case in relation to education, wherefore these youngsters went to the largest university cities to build up, and capitalize upon, educational capital.

Thus we see that, for adolescents aiming for upwards social mobility, staying home with 'no opportunities' is equal to no capital building - or, at least no attainment of educational and social capital highly recognised and valid outside the local area within the field of fields, i.e. endowed with prestigious, state legitimized 'super' symbolic capital. Hence no development, no perspectives, no aspirations, no opportunities for ambitious, young people in such a rural area. This in stark contrast to what was the case in the old agricultural communities until the mid 1960s, where a prestigious career as often took place within the local area (becoming a prosperous farmer, a chairman of the local or regional agricultural society or farmer's party etc., see Svendsen and Svendsen 2004). ${ }^{\prime}$

\section{Forms of Capital Left Behind}

\section{Beautiful Nature, Family and Local Communities}

When asked about good things in the municipality, nature was mentioned 15 times - e.g. the forest Klosterheden, the long North Sea beach, as well as the North Sea fjord. For example, 22-year old Laura from the village of Fabjerg, professional bachelor student in Thyholm, not far away from Lemvig Municipality, praised the forest, sea and fjord and, generally, the "many different, beautiful natural resorts".

As often, their childhood was closely interlinked to nature, hence the strong longing of the nature of their birth place in accordance with an embodied, primary cultural capital. The already mentioned engineering student in

\footnotetext{
${ }^{9}$ Regarding problems with the municipality, three interviewees mentioned that a reason to move away was 'the local mentality'. One of them, a 22-year old business school student in Aalborg, Jane, was born and raised in the municipality, her parents were however 'newcomers'. She started the interview by saying: "I don't like the municipality". She thought that she had been treated unfairly by the municipal employees. The municipality is "an ass basher" and Lemvig a "shitty town" as she bluntly put it.
} 
Aarhus, Anders from the village of Bøvling, formulated it in this way: "Good things are nature and things like that, then, I lived in the countryside (...) sometimes I miss that. The North Sea and... less smog [laughter]". Similarly, the beforementioned Flemming from Nissum missed some of the peace and quiet he had experienced in his childhood: "It was a lovely, peaceful area. It wasn't a place where wild things were going on all the time. Well, that may sometimes be an advantage".

The interviewees revealed even more emotions when they talked about the local community. This included friends for life, they had made in close-knit community villages. 13 times this was mentioned - with terms like "a cosy community", as Morten, a 24-year old engineering student, describes his home town Lemvig. They often showed feelings of belonging to a particular regional identity, and a pride of that identity as well. Often words like "secure" and "safe" were used. Several interviewees also mentioned the close social solidarity between youngsters that had been built up in the high school in Lemvig. Signe, a 23-year old university student in Aalborg, who was born and grew up in the village of Nissum, came up with this typical statement:

It's a secure little village [Nissum]. In the beginning [as a child], well, not much was happening, but we all thought it was great (...) I think I, as a child, had a really good social life, rich and easy to overlook (...) And when I went to high school, well I was in a really good class. I know everybody from that time, a really good thing. Socially, I have felt really well.

Villages such as Harboøre, Thyborøn and Bøvling were pointed out as particularly warm, close-knit local communities rich on bonding social capital. For example, asked about what the best thing in the municipality was, Flemming, one of the two engineering students at Aarhus University from Bøvling, exclaimed:

Local solidarity! It just happens that everyone knows each other in Bøvling. There are both advantages and disadvantages connected to that. That everyone knows each other gives you a lot of good contacts. And people really take care of each other.

Ten of the responses referred to friends and family. Several expressed that they missed their family - their parents and siblings. A typical response came from a 23-year old physiotherapist student in Aarhus, Nicoline, who was born and grew up in the village of Thyborøn. She spoke with a pronounced regional dialect and seemed to be profoundly influenced by a regional mentality and the concomitant values: "I think the best thing is that my whole family lives there. They were always so close to me when I grew up. To be so far from them is probably one of the hardest things to endure". Hence, feelings of warmth and security characterized such answers and it was clearly not easy for the youngsters to 'sacrifice' their 'survival' networks.

\section{No 'Native' Capital: NOTHING Left Behind}

As the content analysis testified, most young outmigrants have fairly positive feelings about their native soil, although - as already mentioned - 'too little happens', especially when you have surpassed your teens. That this is a really bad thing, increasing longing, was evidenced by 14 responses falling into this category. "There just comes a time when the cultural opportunities are too few", said Signe, a 23-year old university student in the city of Aalborg. She added that her birth village Nissum is "ghost town number one". Others pointed at the lack of cultural events such as music concerts.

The last answers relate to criticism of the municipality, including the regional mentality as such. Ten answers can be placed in this category. One is from 23-year old Mie - a woman, who was studying sports at Aarhus University. Mie was born and raised in Lemvig. She is a 'local patriot', who is still in close contact with former schoolmates and friends in the municipality. She said the following about living in a small place where everyone knows each other: "It can be a disadvantage if you have made yourself unpopular. The rumour spreads quickly. You can't just go somewhere else (...) Everybody knows who you are".

In contrast to fully integrated and 'homegrown' adolescents like Mie, stands the business school student in Aalborg, Sabrina. Here we have an example of one who feels that she never has been socially accepted. She told me that, several times during her childhood, she had to change school, because she became "doomed by the rumour" [sic]. She felt stigmatized and almost persecuted in a municipality she vehemently described as an "ass basher" [sic], even to this day. She summarized her critique thusly:

Oh, really, it's nothing but a small compressed community consisting of cousins. It's pure inbreeding. Most people are alcoholics and drug addicts (...) There are no activities for young people, therefore they can easily get into crime and drugs. When they are bored, it's easier to find and rob a supermarket than to find a skateboard ramp.

The problems of drunkenness and crime were also mentioned by two other interviewees, neither of whom grew up in the municipality. For example, Silas had been member of a drinking society during his 6 months' stay 
in the municipality. He stated that: "Lemvig is a town of drunkards. There's too much drinking. I myself have been a part of that".

Finally, four mentioned poor public transport. For example, Mie told that she had been very dependent on her parents to drive her around when she was going to visit someone outside Lemvig - 'taxi driving' as she formulated it. Some also mentioned cut-downs in public service and job losses, including schools and hospitals. Anders from Bøvling put it like this:

There are so many public institutions that get closed down. This does not make it particularly attractive to be young there. For example, the public school I went to, it has also been closed down. It's quite limited what has been left since then (...) For example, I went to many clubs as a boy - scouts and things like that. The scouts are gone now. There are fewer activities for young people today.

\section{Considerations of Moving Back}

The questions about what they liked and disliked about the municipality led naturally to a question about whether they had considered moving back. Of the 25 interviewees 11 answered yes and 14 no.

In general, it was difficult for them to clearly answer this question, they were searching for words, and most of them seemed emotionally afflicted when asked about this. In my diary (09-11-2012), I wrote: "It strikes me how personal this question is. I expected it to be a neutral question - easy to answer with either a yes or a no. However, many of them appear somewhat taken aback and confused about this question (which might be understandable), but besides, also surprisingly strongly emotionally affected. And I seldom get a clear answer."

\section{Potential Return Migrants}

Longing for the 'mentality', community life - and a good job!

Among those who seriously considered returning home was the 23-year old university student from Bøvling, Nikolaj, who was studying physics at Aarhus University:

Nikolaj: Yes, I would! [like to return to Lemvig Municipality] Now that I live in Aarbus, I clearly perceive a difference in people's mentality. And also, in the larger cities where people are more reserved and stick more to themselves, I often miss this special relation to the locals. In small villages you have a good relationship with the locals. It's where you grew up that you know people best.

Interviewer: Do you socialize with people from Lemvig Municipality?

Nikolaj: Yes, in fact with one of my... actually two of my friends, I've gone to school with and been together with since kindergarten. One [of them] is fascinated by city life. The second would like to move back.

Interviewer: Do you think you know your old classmates better than your other friends?

Nikolaj: Yes, we know each other much better. Besides, we have another jargon, another way to talk and understand each other. My girlfriend, she is also from Western Jutland, she feels more at ease with her friends from her village, because they're all a little more down to earth.

Interviewer: When would you like to move back?

Nikolaj: When I got my education and a job, so I can afford to buy a house and a car. House prices are another factor, you'll get more for your money [in Lemvig Municipality]. I still have friends and acquaintances [there], but most of my network has moved to Aarbus or other cities. My whole family still lives there. Denmark is not that big, so it [geographical distance] has notbing to say.

The quote contains a number of key themes that go through the interviews, in particular those with the university students: The attachment to the home community, building a social network of old friends from the municipality with whom you feel 'in tune with', the strong regional identity, the longing for the family, looking for the right job as a prerequisite for moving back - and the great attention to what your friends decide to do.

Also another Aarhus University student from Bøvling, 23-year old Anders, would consider returning home - if the right job was there. Hence, educational capital should not be wasted, but converted into economic and symbolic capital. Career in front of belonging: "Well, yes, I'd consider that. If I after having graduating could find a job in the area. It's mostly my job that will decide". He adds that most of his Lemvig friends in Aarhus share this opinion.

Apart from stressing the recurrent theme of giving one's children as good and safe a childhood, the prevalence of a good job also reveals itself in the interview with the already mentioned 23-year old Mie from the town of Lemvig. Her somewhat surprising argument was that the more people crowded together in the big cities, the easier it would be for her to get her dream job in Lemvig:

Mie: I don't know [whether I will return], but I'll not rule it out.

Interviewer: Why not?

Mie: Because, generally, I remember my childhood as a safe place [sic]. It was a good childhood. Most probably, it will be a good place for one's kids to grow up. However, it all depends on where you get a job. I myself have good opportunities to get a job 
as a high school teacher [in Lemvig]. The others [Lemvig friends] are thinking in the same way. They think about it as a good place. Nobody says that they'll go back, however neither that they're ruling it out.

Considering moving back - but a little afraid of losing status

Unlike Mie, another young woman, Nicoline from the close-knit community of Thyborøn, studying physiotherapy in Aarhus at the time of the interview, was in no doubt that she would return home. This was especially due to the amount of network resources 'back home' and, in line with Mie's thoughts, the feeling of security:

Nicoline: Yes! It's primarily because, if I myself am going to have a family, then I'd like to have my own family nearby. That's what I have experienced myself and I greatly appreciate that (...) and then appreciating that my children grow up in a small town - I've enjoyed that myself. I experience that my closest friends are those back from primary school, those who know me best, they're much closer than my Aarhus friends.

Interviewer: Do your friends also consider moving back?

Nicoline: Yes, but then we talk about all of us moving back - as there might be a downside by moving back...

Interviewer: Which downside?... [Silence] Low status?

Nicoline: There might be divergent views here. I'll not say that it cannot be accepted [moving home alone]. On the other hand, it's quite nice that we have a few friends who have stayed back home, it's kind of become a gathering place... when we go home for Easter and Christmas.

Hence, after admitting this 'downside' Nicoline tends to say the unspeakable in her silence and avoidance of the topic - namely that, when outmigrated to a big city, it becomes a little bit disgraceful to return back home, as it implies a loss of a 'locational' symbolic capital, i.e. a social recognition that is attributed to people solely due to their having an address in a big city. As was also indicated in many of the other interviews, returning to your rural native soil is most often associated with not becoming a 'Danish success' and, hence, evokes emotions like shame, disappointment and defeat.

\section{Bringing Your Friends with You: The Lemvig 'Colonies'}

The networks 'brought along' from home - the Lemvig colonies - were mentioned several times in the interviews and gradually became a main theme. The pattern was that the adolescents were not isolated and alienated in the city, because they joined with friends they had known for most of their lives, and these social networks became a kind of substitute for the nuclear family. The oldest and biggest colony was in Aarhus, however colonies were at the time being established in two other university cities, namely in Aalborg and Copenhagen.

A typical representative of the Aarhus colony was the 25 -year old nurse student, Cecilie, originally from the village of Thyborøn:

Well, I would not mind moving back to western Jutland. However, I have married one from [the nearby village of] Hvide Sande, then I might end up there (...) The local communities there are something special. If you yourself are going to have children, then there is the opportunity to give them what you got yourself. The thing about having friends from early childhood, and who follow you the rest of your life. And that's why, in Aarhus, we join each other. That's the way it is. Among fellow students, one might find new friends as well. And if it's someone who is really close, then she will be introduced to the others [laughter].

Overall it appeared that the outmigrants from the close-knit, neighbouring communities of Thyborøn and Harboøre were rich on 'ethnic' bonding social capital, both at their native place and their new place. Asked about whether her friends in Aarhus come from Thyborøn, Cecilie answered:

Cecilie: Well, mostly from Harboore, about 20 to 25... That's how it is, you don't do anything yourself...

Interviewer: What do you mean?

Cecilie: Well, that's because, if two [from the home area] are moving to Aarbus, then they'll join as well. We resemble each other, that's why...

Interviewer: Would you prefer to socialize with people you know beforehand?

Cecilie: Yes, I would. That [Thyboron] is a village (...) where you find people with the same interests. People who are used to all that about living in a small local community... who care for each other in another way than people do in a big city (...) That's your approach to everything... that you care. Those [from Harboore and Thyboron], you can easily join with them. In Thyboron all people know each other. Therefore, you simply bave an inner obligation to take care of all the others. At least, that's bow I think about it.

As mentioned, apart from the most popular Aarhus colony (or colonies rightly speaking), an Aalborg and a Copenhagen colony were being established at the time. Majbrit, 25-year old student in public health at the 
University of Copenhagen explained that she had preferred to go to Aarhus, because most of her high school friends had moved to that city. And she further explained:

Majbrit: When I moved over here [to Copenhagen], there were only a couple [of Lemvig outmigrants]. But now there are more and more moving to Copenhagen.

Interviewer: Do you mostly meet with old friends from Lemvig Municipality?

Majbrit: It's a mix between people from Lemvig and people from my study.

Interviewer: Why do you stick to your old friends?

Majbrit: Well, there are some old friends, going long back [in childhood]... With the same jargon, the same humour.

Interviewer: How do you from Lemvig manage to stick together, how do you communicate?

Majbrit: Facebook! Primarily Facebook.

A similar, new colony was being established in Aalborg, at the northern part of peninsular Jutland, as I was told by thee 23-year old Signe, student at Aalborg University.

\section{No Return! Ot?...}

Regarding the 14 who did not wish to return to the municipality, many emphasized the many opportunities they could only find in larger cities. A typical comment came from the 23-year old carpenter, Tobias, born and grown up in the small village Ferring: "I don't think [I'll return], no. It doesn't mean a thing to me. I just like to live in Holstebro". Another carpenter and 'near' outmigrant, Jacob, who grew up in the village of Gudum and also lived in Holstebro, gave a similar answer: "No, not at all! Well, I think it's just too far from everything! There are not many young people who move away from there (...) I don't have much affiliation there anymore."

Kenneth, 25 years of age and one of the two engineering students from Bøvling, was also very clear-cut in his answer: "Nay, it's wholly unattractive! There are not many attractive jobs. People with higher academic educations would most likely not go to such places. And if you as an employer want to start something up, you'll have problems with recruiting qualified personnel".

About half of the non-returners were less categorical. Many of them would not directly rule out that they would return to their region (western Jutland), although probably not to Lemvig Municipality. One typical statement came from Flemming, grown up in Nissum and at the time of the interview studying business economics at Aarhus University: "I don't know whether it exactly will be back to Lemvig Municipality, however it might well be something similar when I'm going to have family and children... a small village".

Another good example is the aforementioned 23-year old university student in Aalborg, Signe. At the time of the interview she was evidently sad, complaining of her cold concrete apartment in Aalborg - and in general missing nature, family and friends.

Signe: Uh... yes, well, not exactly... Well, at least I've considered moving to the countryside. But whether it should be Lemvig... Well, it was a good childhood, so in that sense it's a good municipality. But there are those years between 15 and 30 when one definitely doesn't want to stay there.

Interviewer: Why have you considered moving to the countryside?

Signe: Nature and stuff. It's hard to live without.

Another typical statement came from 23-year old Majken, who studied medicine at Aarhus university, again showing the dilemma between longing and belonging:

Majken: I wouldn't leave out that option, for sure. Because I think that, nevertheless, it's a good town [Lemvig] ... and there are some initiatives.

Interviewer: Do you bave friends from Lemvig Municipality?

Majken: Yes, half of them are. My best friend comes from Lemvig Municipality.

Interviewer: Do you sometimes talk about moving back?

Majken: No, we don't.

Hence we see that it is not easy to unite 'primary' cultural capital, educational capital, supra-local and local social capital. Moreover, decisions are often impacted by the possibility of getting a good job and good income (economic capital) on the one hand, and social conformity on the other. The latter includes a concern of losing symbolic capital - that is, simultaneously losing face with people who know you and not succeeding in achieving social upward mobility. This is clearly something that often lurks in the back of the heads of the more ambitious and resourceful adolescents who definitely want to become 'successes' and not 'failures'.

\section{Belonging and Capital Investment Strategies}

\section{Two Striking Things}

What really came as a big surprise to me during these interviews were essentially two things. First of all, I was simply amazed by their strong place attachment, that is attachment to their home areas specifically and their region 
BELONGING: Local capital 'left behind'

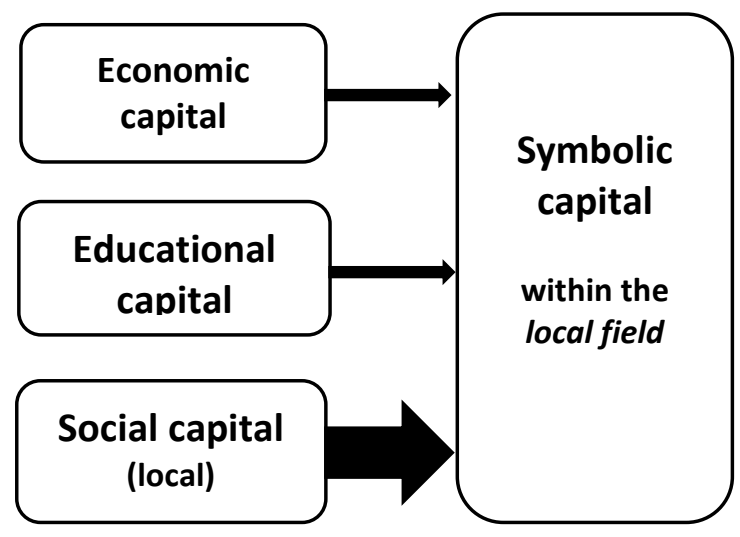

LONGING: Capital achieved

Note: The arrows illustrate the degree of convertibility into symbolic capital.

Figure 4. Young rural-to-urban migrants: Local capital 'left behind' and capital achieved (model figure)

(Western Jutland) more generally, including their pride in being from this area. I myself am born and grew up in a place near Lemvig Municipality (the small town of Vinderup, close to Holstebro), also Mid Western Jutland something that I openly revealed to the interview persons (which would, indeed, also be impossible not to reveal due to my dialect!). I have, however, never felt this belonging and pride, or at least not as strongly as most of them felt. Hence, the great power of 'belonging' - making up a large part of the emotional 'footprints' from our past in the form of human warmth and a feeling of security - gradually became clear to me. It was imprinted in their identity, values, personality and behaviour. The longing for the 'first' life of your life - primary school friends, nature, your parents and siblings, playing soccer, going fishing... And, really, it should be strong to be able to counterbalance push factors like 'nothing ever happens', 'no jobs', 'fewer public services', 'declining associational life', 'outskirt Denmark' combined with pull factors like higher education, 'all my friends live in Aarhus', exotic city life and the pride of yourself (and of your increased symbolic capital) of a postal code as 8000 Aarhus C or 1050 Copenhagen C (in contrast to 7620 Lemvig or 7500 Holstebro).

Another thing that stroke me was the prevalence of networks of young Lemvig outmigrants in the university cities, that is, what I have termed the Lemvig colonies. As a youngster, I myself travelled the long way (culturallymentally), from my home town to Aarhus in order to study anthropology, however without becoming member of a 'local' network in the city. I lost my previous social capital and had to start from scratch. However, luckily this seems not to be the case for many rural university students today.

In my diary (01-11-2012), I wrote the following: "An interesting (emergent) pattern is that they so to speak have brought their circle of friends with them in their 'luggage' - for example, to Aarhus. Then, a couple of times per year, or more, they all meet - the expatriates' circles and their previous school mates still living in the municipality, for example in Lemvig or in Thyborøn (December 2, December 25, during Easter, etc.)".

Hence, today's adolescents seem to reduce the risk of their investment in (urban) capital (educational and symbolic primarily) by keeping in contact with friends and family from their local communities and - not least continue to cultivate and benefit from 'old' social capital, that is, much in line with what is the case with immigrants from other countries (e.g. Portes and Sensenbrenner 1993, Levitt 2001).

\section{Belonging and Capital Investment Strategies - A Model}

Figure 4 seeks to summarize my findings in a model figure. According to both the questionnaire survey and the 25 interviews, important capital left behind is social capital in the form of family, friends and people from the local community, providing the youngsters security and predictability. Besides this, the youngsters exhibited strong place attachment. Local social capital adheres to a local/regional identity (or 'mentality' as many of the interviewees mentioned) and, most often, a strong belonging, not least among the more ambitious of the adolescents who have migrated to the university cities. Hence, in the local setting social capital is by the youngsters seen as the most valuable capital form, or 'master capital', immediately convertible to social recognition (symbolic capital) in a particular, local field, in the figure illustrated by a thick arrow. Economic and educational capital are of much less importance in the local field in respect to convertibility to symbolic capital, which is illustrated by the thin arrows. 
In contrast, in what regards capitals to be achieved educational capital is clearly the master capital (thick arrow), at least among the 'remote' outmigrants. This capital form achieved at the universities and other longer educations is highly valid, state guaranteed and useable in practice at the national (and/or international) level, that is in the 'field of fields'. It makes possible for these 'longing' youngsters to establish careers and upwards social mobility, good incomes, free mobility etc. and thus achieve the highest form of social recognition in society - a kind of 'super' symbolic capital. However, many of them do not simply skip their 'old' social capital built up through their childhood and early youth. Therefore, they prefer to move to the cities together with old friends and, often, share apartments with them. Hence, they lower the risk of a 'bad' trade-off, although many of them still feel a sting in the heart when thinking about the native places they have left, due to their social and place attachment. In comparison, the 'near' outmigrants did not to the same degree form 'Lemvig colonies' and therefore seemed to be more isolated at their new locations.

Finally, as regards potential return migration there was certainly a longing among most adolescents, and especially among the more resourceful, remote outmigrants, to go back home to their home region, Western Jutland. However, this was only provided that they would be able to use their achieved resources - that is, primarily high educational capital - in getting well-esteemed, interesting and well-paid jobs.

\section{CONCLUSION}

In recent years, we have seen a global trend of rural adolescents moving to big cities in search for educational opportunities and well-paid, prestigious jobs (e.g. Argent and Walmsley, 2008; Champion, 2012). In this context, previous studies reveal that many adolescents have to make a painful choice between staying and migrating, that is, between attachment to their birth place and their career ambitions. In this way these young people become 'trapped' between the warm, secure local communities of their childhood and ambitious career strategies, i.e. their belonging to a specific socio-space characterized by 'survival' networks (Corbett, 2013), where capitals are directed towards a local/regional field; and their longing for a non-specific, other place where they can get a career and increase cultural, economic and symbolic capital that can be applied within the national field (cf. Hektner, 1995; Johnson et al., 2005; Bourdieu, 2014). What has however been less investigated is the youngsters' second choice: After a period of time, they have to decide whether they should remain at the new place and use their achieved capital there, or return home to their native place and make use of it there.

On this background, and using a case from rural Denmark within a combined Belonging (Cohen, 1982; Corbett, 2013) and Bourdieusian forms of capital (Bourdieu, 1986; Svendsen and Sørensen, 2007; Bosworth and Turner, 2018) theoretical framework, the contribution of this paper was threefold: To give an insight in rural adolescents' relocation motives, their attachment to their birth place, as well as their reasons for considering, or not considering, to return to their native place. Hence, the purpose was to shed light on the following three, closely interrelated questions:

\section{Why Do Young Rural-urban Migrants Leave Their Places of Birth, What Do They Leave Behind, and Do They Consider Moving Back Later in Life?}

Results were reported from two studies in the Danish rural municipality of Lemvig, namely a 2011-survey study that included 120 outmigrants and a telephone interview study in November 2012 including 25 youngsters.

Both the survey and the interviews showed that the main reasons for moving out of the municipality were common sense considerations about getting a job or an education, that is, educational and career ambitions. These considerations rooted in emotions of personal pride and wish of social recognition in the eyes of the world. Moreover, the survey showed that adolescent outmigrants found nature, social networks and quiet surroundings most attractive in their home municipality, that is, an indicator of strong place and social attachment. In line with this, the telephone interviews with 25 young outmigrants clearly showed that they found themselves trapped between two 'competing' sets of feelings: Warmth and security versus personal pride, ambition and high selfesteem. On the one hand, important capital left consisted mainly in local social capital (friends, family, local communities) associated with strong local and regional identity, i.e. belonging, linked to warmth, security and primary (childhood) cultural capital. On the other hand, the most ambitious adolescents were convinced that in their home municipality there would be too few opportunities in the form of jobs, education and cultural activities ('nothing ever happens'). They therefore chose to become university students in the big cities to achieve the most powerful and state-legitimized form of educational capital, with the hope to get prestigious careers and, thus, enjoy 'super' symbolic capital, that is, social recognition that stretches far beyond their local communities.

One should then think that the young outmigrants had skipped their 'native' social capital and were forced to build up new networks from scratch. This was however not the case. Many of them moved to the cities together with friends and formed what I have referred to as 'Lemvig colonies'. In this way, they preserved their most valuable social capital. 
Finally, the interviews showed that, within many adolescent outmigrants, an 'inner fight' was going on between career and security considerations concerning future settlement. This included considerations of returning home at some point in time, or at least moving back to the region. 11 out of 25 wanted to move home to Lemvig Municipality, whereas many of the others would not rule it out - at least, they considered returning back to the region (Western Jutland). Especially the more resourceful, 'remote' outmigrants who seemed to have the most privileged family backgrounds (14 out of the 25), mostly university students, were interested in returning, and overall they seemed to have very strong place and social attachment. However, going back home would demand that they were offered well-esteemed, interesting and well-paid jobs, ensuring that they did not waste their high educational capital and, thusly, lose face.

Future research might focus more on the 'second choice' of young rural-to-urban migrants, including their rational-emotional motivations to return back to their native places. In that context, it is also important to investigate effects of social recognition (and misrecognition), as well as discourses of rurality at the national level. Ideally, panel studies should be preferred in the form of repeated surveys or in-depth interviews, or both, with the same group of youngsters during a longer time period. This would be to get a more precise picture of how adolescents cope with migrating to the cities, whether they preserve their attachment to their native places, and how their future settlement plans develop over time.

\section{REFERENCES}

Alston, M. (2004). 'You don't want to be a check-out chick all your life': The out-migration of young people from Australia's small rural towns. Australian Journal of Social Issues, 39, 299-313. https://doi.org/10.1002/j.18394655.2004.tb01178.x

Argent, N. and Walmsley, J. (2008). Rural youth migration trends in Australia: an overview of recent trends and two inland case studies. Geographical Research, 46(2), 139-152. https://doi.org/10.1111/j.17455871.2008.00505.x

Baños, F. V. (2017). The field of fields. The state according to Pierre Bourdieu. Culture \& History Digital Journal, 6(1), 1-10. https://doi.org/10.3989/chdj.2017.010

Barbalet, J. M. (1998). Emotions, Social Theory, and Social Structure. Cambridge University Press, Cambridge. https://doi.org/10.1017/CBO9780511488740

Barratt, C. (2012). Between town and country: shifting identity and migrant youth in Uganda. Joumal of Modern African Studies, 50(2), 201-223. https://doi.org/10.1017/S0022278X1200002X

Bericat, E. (2016). The sociology of emotions: Four decades of progress. Current Sociology, 64(3), 491-513. https://doi.org/10.1177/0011392115588355

Bezu, S. and Holden, S. (2014). Are rural youth in Ethiopia abandoning agriculture? World Development, 64, 259272. https://doi.org/10.1016/j.worlddev.2014.06.013

Bjarnason, T. and Thorlindsson, T. (2006). Should I stay or should I go? Migration expectations among youth in Icelandic fishing and farming communities. Journal of Rural Studies, 22(3), 290-300. https://doi.org/10.1016/j.jrurstud.2005.09.004

Bosworth, G. and Turner, R. (2018). Interrogating the meaning of a rural business through a rural capitals framework. Journal of Rural Studies, 60, 1-10. https:// doi.org/10.1016/j.jrurstud.2018.02.002

Bourdieu, P. (1979a). Le capital social. Actes de la recherche en sciences sociales, 31, 2-3.

Bourdieu, P. (1979b). Les trois états du capital culturel. Actes de la recherche en sciences sociales, 31, 3-6. https://doi.org/10.3406/arss.1979.2654

Bourdieu, P. (1986). The forms of capital. In: Richardson, J.G. (ed.), Handbook of Theory and Research for the Sociology of Education, pp. 241-58. Greenwood Press, New York.

Bourdieu, P. (2005). The Social Structures of the Economy. Polity Press, Cambridge.

Bourdieu, P. (2014). On the State: Lectures at the College de France 1989-1992. Edited by Patrick Champagne, Remi Lenoir, Franck Poupeau, and Marie-Christine Riviere. Cambridge, Polity Press.

Burt, R. (1992). Structural Holes: The Social Structure of Competition. Harvard University Press.

Champion, A. (2012). Europe's rural demography. In: International Handbook of Population, pp. 81-93. Springer, Netherlands. https://doi.org/10.1007/978-94-007-1842-5_7

Cohen, A. P. (1982). Belonging: Identity and social organization in British rural cultures. Manchester University Press.

Cohen, A. P. (1985). The Symbolic Construction of Community. Routledge, London and New York. https:// doi.org/10.4324/9780203323373

Coleman, J.S. (1994). A rational choice perspective on economic sociology. In: Smelser, N.J. \& Swedberg, R. (Eds.), The Handbook of Economic Sociology, pp. 166-78. Princeton University Press, New York.

Christensen, J. (2017). Urbaniseringens konsekvenser siden 1926. Analysenotat. Kommunernes Landsforening. 
Cottingham, M. D. (2016). Theorizing emotional capital. Theory and Society 45, 451-470. https://doi.org/10.1007/s11186-016-9278-7

Cruickshank, J., Lysgård, H.K. and Anderssen, M.-L. (2009). The logic of the construction of rural politics: Political discourses in Norway. Human Geography, 91(1), 73-89. https://doi.org/10.1111/j.1468-0467.2009.00307.x

Danish Ministry of the Interior and Health. (2005). Kommunalreformen - kort fortalt. Indenrigs-og Sundhedsministeriet, Copenhagen.

Eastman, J. T. (2013). Youth migration, stratification and state policy in post-Soviet Russia. Sociology Compass, 7(4), 294-302. https://doi.org/10.1111/soc4.12030

Gabriel, M. (2002). Australia's regional youth exodus. Journal of Rural Studies, 18, 209-212. https://doi.org/10.1016/S0743-0167(01)00039-0

Glendinning, A. Nuttall, M., Hendry, L., Kloep, M. and Wood, S. (2003). Rural communities and well-being: A good place to grow up? The Sociological Review, 51(1), 129-156. https:// doi.org/10.1111/1467-954X.00411

Goleman, D. (1996). Emotional Intelligence. Why it can matter more than IQ. Bloomesbury Publishing.

Gustafsson, H. (2001). Trends in Swedish rural and populated areas. Available at: http://www.glesbygdsverket.se (Accessed 02 July 2013).

Halfacree, K. H. (1994). The importance of 'the rural' in the constitution of counterurbanization: Evidence from England in the 1980s. Sociologia Ruralis, (2-3), 164-189. https://doi.org/10.1111/j.1467-9523.1994.tb00807.x

Halfacree, K.H. (1995). Talking about rurality: social representations of the rural as expressed by residents of six English parishes. Journal of Rural Studies, 11, 1-20. https:/ / doi.org/10.1016/0743-0167(94)00039-C

Hektner, J.M. (1995). When moving up implies moving out: Rural adolescent conflict in the transition to adulthood. Journal of Research in Rural Education, 11(1), 3-14.

$\mathrm{Hu}, \mathrm{X}$. (2012). China’s young rural-to-urban migrants: In search of fortune, happiness, and independence. Migration Information Source, January 2012.

Jamieson, L. (2000). Migration, place and class: youth in a rural area. The Sociological Review, 48(2), 203-223. https://doi.org/10.1111/1467-954X.00212

Jessop, B. (2015). The central bank of symbolic capital. Bourdieu's On the State. Radical Pbilosophy 193(1), 33-41.

Johnson, M. K., Elder, G. H. and Stern, M. (2005). Attachments to family and the community and the young adult transition of rural youth. Journal of Research on Adolescence, 15(1), 99-125. https://doi.org/10.1111/j.15327795.2005.00088.x

Jones, G. (1999). 'The same people in the same places?' Socio-spatial identities and migration in youth. Sociology, $33(1), 1-22$.

Kloep, M., Hendry, L. B., Glendinning, A., Ingebrigtsen, J.-E. and Espnes, G. A. (2003). Peripheral visions? A cross-cultural study of rural youths' views on migration. Children's Geographies, 1(1), 91-109. https://doi.org/10.1080/14733280302189

Levitt, P. (2001). The Transnational Villagers. University of California Press, Berkeley and Los Angeles.

Lumb, R. (1980). A community-based approach to the analysis of migration in the highlands and islands of Scotland. The Sociological Review, 28(3), 611-627. https://doi.org/10.1111/j.1467-954X.1980.tb00381.x

Ministry of Housing, Urban and Rural Affairs, (2013). Landdistriktsredegorelse 2013: Available at: https://www.livogland.dk/files/dokumenter/publikationer/regional_og_landdistriktspolitisk_redegoerelse_2 013.pdf (Accessed 08 July 2018).

Municipal Statistics (2018). De Kommunale Nøgletal. Statistics Denmark. Available at: http://www.noegletal.dk (Accessed 01 July 2018).

Ni Laoire, C. (2000). Conceptualising Irish rural youth migration: A biographical approach. International Journal of Population Geography, 6, 229-243. https://doi.org/10.1002/1099-1220(200005/06)6:3<229::AIDIJPG185>3.0.CO;2-R

Ni Laoire, C. (2007). The 'green green grass of home'? Return migration to rural Ireland. Journal of Rural Studies, 23, 332-344. https://doi.org/10.1016/j.jrurstud.2007.01.005

Nilsson, B. and Lundgren, A. S. (2015). Logics of rurality: Political rhetoric about the Swedish North. Journal of Rural Studies, 37, 85-95. https://doi.org/10.1016/j.jrurstud.2014.11.012

Nugin, R. (2014). "I think that they should go. Let them see something". The context of rural youth's outmigration in post-socialist Estonia. Journal of Rural Studies, 34, 51-64. https:// doi.org/10.1016/j.jrurstud.2014.01.003

Nørgaard, H. (2012). Tilflyttere til yderområder: Flyttemotiver, sociale relationer og hjemfølelse. In: Svendsen, G.L.H. (ed.) Livsvilkår og udviklingsmuligheder på landet: Viden, cases, teorier, pp. 208-215. Syddansk Universitetsforlag, Odense, Denmark.

Polanyi, K. (1977). The Livelihood of Man. New York, San Francisco, London, Academic Press.

Portes, A. and Sensenbrenner, J. (1993). Embeddedness and immigration: notes on the social determinants of economic action. American Journal of Sociology, 98(6), 1320-1350. https://doi.org/10.1086/230191 
Rosvall, P.-Å., Rönnlund, M. and Johansson, M. (2018). Young people's career choices in Swedish rural contexts: Schools' social codes, migration and resources. Journal of Rural Studies, 60, 43-51. https://doi.org/10.1016/j.jrurstud.2018.02.007

Rye, J. F. (2006). Rural youth's images of the rural. Journal of Rural Studies, 22, 409-421. https://doi.org/10.1016/j.jrurstud.2006.01.005

Seyfrit, C. L., Bjarnason, T. and Olafsson, K. (2010). Migration intentions of rural youth in Iceland: Can a largescale development project stem the tide of outmigration? Society and Natural Resources, 23, 1201-1215. https://doi.org/10.1080/08941920903278152

Stockdale, A. (2002a). Outmigration from rural Scotland: The importance of family and social networks. Sociologia Ruralis, 42(1), 41-64. https:/ / doi.org/10.1111/1467-9523.00201

Stockdale, A. (2002b). Towards a typology of outmigration from peripheral areas: A Scottish case study. International Journal of Population Geography, 8, 345-364. https://doi.org/10.1002/ijpg.265

Svendsen, G. L. H. (2003). Vi bilser da på hinanden... De nye tilfyttere $i$ Ravnsborg Kommune: Problemer og muligheder. CLF Report Series, Vol. 5/03. University of Southern Denmark, Esbjerg.

Svendsen, G. L. H. (2013). Mellem folelser og fornuft: Til- og fraflyttere $i$ Lemvig Kommune, med fokus på de unge fraflyttere. CLF Report Series, Vol. 20/13. University of Southern Denmark, Esbjerg.

Svendsen, G. L. H. and Sørensen, J. F. L. (2007). There's more to the picture than meets the eye: Measuring tangible and intangible capital in two marginal communities in rural Denmark. Journal of Rural Studies, 23, 453-471. https://doi.org/10.1016/j.jrurstud.2007.01.008

Svendsen, G. L. H. and Sørensen, J. F. L. (2016). Skolelukninger på landet: En undersogelse af skolelukningsforlob i Tonder Kommune 2010-11, samt lukningernes konsekvenser for de berorte lokalsamfund. CLF Report Series, Vol. 56. University of Southern Denmark.

Svendsen, G. L. H and Svendsen, G. T. (2003). On the wealth of nations: Bourdieuconomics and social capital. Theory \& Society, 32(5/6), 607-631. https://doi.org/10.1023/B:RYSO.0000004967.97783.c4

Svendsen, G. L. H. and Svendsen, G. T. (2004). The Creation and Destruction of Social Capital: Entrepreneurship, Cooperative Movements and Institutions. Cheltenham, UK, and Northampton, MA, USA, Edward Elgar.

Sørensen, J. F. L. (2014). Rural-urban differences in life satisfaction: Evidence from the European Union. Regional Studies, 48(9), 1451-1466. https:/ / doi.org/10.1080/00343404.2012.753142

Swedberg, R. (2011). The economic sociologies of Pierre Bourdieu. Cultural Sociology, 5(1), 1-18. https://doi.org/10.1177/1749975510389712

Thuesen, A. A. (2012). Luft omkring dig. Om tilflytning og institutionel kapacitet i fem danske landsogne. In: Svendsen, G. L. H. (ed.) Livsvilkår og udviklingsmuligbeder på landet: Viden, cases, teorier, pp. 225-230. Syddansk Universitetsforlag, Odense, Denmark.

VisitNordjylland (2017). Lemvig-Thyborøn Touristguide 2017: Available at: https://issuu.com/visitnordvestjylland/docs/visitnordvestjylland_turistguide_17 (Accessed 16 April 2018).

White, A. (2010). Young people and migration from contemporary Poland. Journal of Youth Studies, 13(5), 565-580. https://doi.org/10.1080/13676261.2010.487520

Waldstrøm, C. and Svendsen, G. L. H. (2008). On the capitalization and cultivation of social capital: Towards a neo-capital general science? Journal of Socio-Economics, 37(4), 1495-1514. https://doi.org/10.1016/j.socec.2007.06.009

Wiborg, A. (2004). Place, nature and migration: Students' attachment to their rural home places. Sociologia Ruralis, 44(4), 416-432. https:/ / doi.org/10.1111/j.1467-9523.2004.00284.x

Wilson, G. A. (2012). Community resilience and environmental transitions. Abingdon: Routledge.

Winther, M. B. and Svendsen, G. L. H. (2012). The rotten banana fires back: The story of a Danish discourse of inclusive rurality in the making. Journal of Rural Studies, 28(4), 466-477. https://doi.org/10.1016/j.jrurstud.2012.05.003 